\author{
Seligi A. M., \\ Student \\ of the Kherson National Technical University
}

Hnedko T.M., Senior Lector of the Chair of Theory and Practice of Branch Translation Kherson National Technical University

\title{
THE FUNCTION OF CONVERSE TERMS IN ENGLISH TEXTS OF DIFFERENT STYLES
}

Summary. The phenomenon of conversion has been of interest to linguists for many centuries. It is one of the main ways of word formation in the English language and in recent decades, has become one of the most productive. Despite its prevalence in modern English, and the availability of a great deal of scientific research on the issue types, functions, and features of conversion - its study remains one of the most relevant questions in modern linguistics.

The phenomenon of conversion is so active in modern English that it is-involved, albeit with unequal frequency, in practically all parts speech - such as nouns, verbs, adjectives. Moreover, conversion is most characteristic of English for the following reasons. First, because of its analytical structure, including the almost complete absence of morphological indicators of parts of speech in it (i.e. they either do not differ at all, or may differ in word-forming affixes). Second, conversion appears throughout the history of the English language. For example, elements of Old English were widely used to create new words in modern English vocabulary, including monosyllabic words, from which new words were created by affixation and word formation.

Conversion as a means of word formation is widely used in texts of different styles and genres. The proposed article investigates the extent to which conversions in texts of different styles are spread, based on their genre and style characteristics. Further, it analyzes the functions of words formed in this way, in order to establish for future study possibilities for more equivalent and adequate ways of translating them from English into Ukrainian (in which this the way of word formation is almost absent) in texts of different styles and genres. In each case, conversion performs specific functions. In literary contexts, converse terms depict the individual style of the author, a particular dialect or way of speaking of a character and/or their worldview. In scientific contexts, converse terms are used as a means of synthesizing information, through concretization and conciseness. In nonfiction contexts, converse terms have both an expressive function, as well as means for generalization. Overall, conversion as a word-forming tool is not equally common in texts of different styles.

Key words: word formation, conversion, morphological indicators, genre and style characteristics, expressive function, compression function.

Formulation of research question. The phenomenon of conversion has been of interest to linguists for many centuries. The term was first used in the late nineteenth century. Despite its wide usage in modern English today, as well as the availability of a large amount of scientific research on this form of word building (for example the works of: Kverk R. [1], Meshkov O. [3]), Vysochinsky Y. [4], Zabotkina V. [5]), the issue of conversion remains one of the most debated and relevant in the modern linguistics. Because conversion is very common in English, and it affects the meaning of a large number of words in texts of any style or genre, conversion is often a challenge- for future or working translators who work with these texts of different styles and genres.

Statement of objectives and research tasks. The purpose of this paper is to help elucidate the function of lexical units when formed by conversion in texts of different styles, in order to analyze them for more equivalent and adequate translation in texts of different styles and genres.

Presentation of materials with justification of obtained results. It should be noted at the outset that the classification of converse terms is extremely diverse. First, converse terms are formed by a large number of models: verbalization (verb formation), substantiation (noun formation), adjectivization (adjective formation), and adverbialization (adverb formation). Second, conversion has an even greater number and variety of semantic connections beyond affixation. The semantics of a derivative verb or noun are not limited by the meaning of the word-forming affix, but are formed under the influence of connectivity, which gives the newly formed words greater semantic capacity. In many cases, converse terms are ambiguous. However, conversion as a means of language enrichment by neologisms is also widespread in texts of different styles and genres. In this case, the newly formed word has a specific function.

Texts of literary style are distinguished by their imaginativeness and expressiveness. Due to these special expressive and aesthetic qualities, it stands out among other varieties of literary language writing. For example, fiction is a form of social consciousness, a mirror of reality. It is sensitively responsive and comprehensively reproduces the multifaceted phenomena of social life. For this reason, such literary works often use a variety of linguistic elements, some of which are contained not so much in the language of the author's direct speech, but also in the language of the characters themselves, as a means of verbal and artistic imagery. Thus, by examining the composition of linguistic elements, we can see that the texts of literary style can differ significantly different from other styles of language.

However, it would be wrong to completely separate literary style from other styles. Literary style absorbs components of all other functional styles - transforming and rethinking them. For example, it makes extensive use of language units belonging 
to different periods of history, as well as social and territorial variations of the national language. In terms of the openness of its stylistic system, the language of fiction, for example, is closest to spoken style. This style is actively used in the language of folklore, through non-normative and non-codified linguistic means, such as archaisms, historicisms, dialectics, and neologisms. In the literary style, samples of the norms of literary language are normative language can be reproduced, but there is also modification, the renewal of expressive means, and the addition of "national color" to the emotional reflection of reality that is transmitted.

It should also be noted that unity of communicative and aesthetic functions is apparent not only in literary style. Aesthetic qualities, such as emotionality and expressiveness, are also characteristic of nonfiction works and scientific works. For example, the language of public speaking by agitators and propagandists has always been characterized by emotional and expressive appeals, through purposefulness, passion, confidence, liveliness and imagery, as well as the qualities of accuracy, comprehensibility, and accessibility.

Often, converse terms in the literary texts have a hidden meaning, often reflecting the style of the author or character of the work, the features of the dialect or worldview, and/or the flow of thoughts. For example: "I can candy him and sit him down on the potty a hundred times a day".

Conversion also plays an important role in enriching the vocabulary of scientific style. Scientific style is a style of writing used in various fields of science and technology. It is characterized by the widespread use of terminology, foreign language, and abstract vocabulary. However, words are used only for their direct meaning, and often in complex sentences. There are substyles to this genre: popular science (topics readily available to the mass reader), and journalism. The scientific style does not often use imaginative language, including dialects and/or vulgar words.

We can examine some specific characteristics of scientific and technical texts: static character, laconism, cohesion and coherence; widespread use of abstract vocabulary and a specific way of its substantiation; the specific coherence of abstractness and generalization, as a way of scientific knowledge presentation. Further, when analyzing individual stylistic features of a particular author, the verbal or nominal character of the style is often apparent, depending on what stylistic elements the author prefers to use, such as dynamic verbs, or nouns and adjectives that create the static character of the text. Verbs in the function of prepositions are used in the scientific literature on average twice less often than nouns and adjectives, which gives us reason to think about the nominal character of scientific and technical literature. This phenomenon is quite natural and understandable: certain concepts in scientific literature are specified and defined in more detail, and in more versatile ways, than in literature.

The purpose of scientific and technical texts also affects their linguistic style, such as the desire for brevity and conciseness. In scientific and technical texts, cumbersome language is a real danger, because intelligibility can be lost. Therefore, in the case of scientific and technical texts, cumbersome and incomprehensible expressions are often replaced (and consolidated) through laconic mathematical symbols and formulas [2, p. 66].

Further, affix-less derivatives, as well as compound words, also contribute in synthesizing information in scientific texts. However, the number of new words produced by this method is much lower than in literary and journalistic texts. The fact is that the above- mentioned features of the scientific style create altogether different stylistic constraints, which require compliance with prevailing language norms, and do not allow for the frequent use of converse terms. Converse terms are usually found in informal documents and articles. However, the most common converse terms found in scientific and technical texts are those of the noun-verb model. For example: "Multihulls peak higher and sooner than monohulls and capsize at lower angles".

The originality of non-fiction texts is thus due to several circumstances, including the wide range of issues and subjects that are often addressed therein. Journalism appeals to a very large audience; it not only informs, but also strives, above all, to influence readers' minds and feelings in a certain way, to form a certain idea of the facts and events presented. Therefore, certain conditions apply to the language of journalism - a journalistic text must be clear, logical, convincing, and expressive to the target reader.

The journalistic style is similar to the literary style, in that it also has to rework texts and terms created within other styles. Scientific and technical styles are focused on the intellectual reflection of reality, and literary language focuses on emotional imprint. Journalism plays a special role in seeking to satisfy both intellectual and aesthetic needs. Among the main linguistic features of the journalistic style are the fundamental heterogeneity of stylistic means, the use of special terminology and emotionally colored vocabulary, and the use of both abstract and specific vocabulary.

Journalism is the main field of origin and the most active channel for the spread of linguistic neologisms (lexical, word-forming, phraseological). Therefore, this style has a significant influence on the development of language norms. The journalistic style covers a wide range of vocabulary, from that of literary language, to scientific and technical terms, to words spoken in everyday language. The text of newspapers is characterized by the presence of proper names, a large percentage of numerators, a large number of dates, international words, a tendency to innovate, a large percentage of abstract words, and a large amount of evaluative and expressive vocabulary.

Conversion is one of the most common means of generating new words in journalistic texts, especially through substantiation and verbalization. Most often, we find this kind of word-formation in the headlines. Converse terms allow you to convey a desired amount of information using fewer words and phrases, while also sometimes having an extra expressive function. For example, substantiation occurs when subject to words is belonging to different parts of the language, such as the verb: "Put the Freeze on Interest", "Freezing Profit"; adverbs: "The Ups: Food, Rent Rates, Fare, etc.". "Increased prices for food, housing, travel, etc.". Not all types of word transitions into another part of the speech lead to the formation of a new word; often it is simply the use of a word functionally as another part of speech. For example, using the adverbs "yes" and "no" in the function of a noun: "The Leaders Expect a Mighty 'Yes"' and "Sign the National 'NO". Further, newspaper headlines often include examples of adverb verbalization, such as: "Action to Up Pensions".

Conclusions and further research prospects. Conversion is productive in texts of any subject matter, both verbal and written. We have found that this type of word-formation is most common in literary texts, because it most often is used to reflect a specific author's style and promote the formation of new concepts, which can only be understood in that context. Conversion is less commonly 
used in journalistic texts; instead, substantiation and verbalization, for example, are used to form many headlines headings, are the most common ones. Conversion is used the least in scientific and technical texts, but is used productively and expediently when it is. Since one of the main features of the scientific style is conciseness and clarity, when converse terms are used, they often refer to an action, especially within the noun-verb model. The purpose of our further study will be to identify the most equivalent and adequate ways to reproduce in Ukrainian converse terms (taking into consideration the fact that converse terms are not widely used in the Ukrainian language) when translating texts of so many different styles.

\section{References:}

1. Kverk R. Style and Communication in English. Social Sciences Abroad. Linguistics. 1984. № 6. P. 200-209.

2. Kurashvili EI About the basic characteristics of the English scientific and technical text. Foreign languages in high school. 1992. № 9. Р. 64-69.

3. Meshkov O.D. Word-formation of the modern English language. Moscow : Nauka, 1976. 245 p

4. Vysochinsky Yu.I. Conversion - one of the ways of replenishing the vocabulary of modern English : diss. ... Candidate of Philological Sciences : 10.664 “Germanic Languages". Kyiv, 1969. 220 p.

5. Zabotkina V.I. The new vocabulary of modern English to the languages. Moscow : Vysshaya shkola, 1989.126 p.

Селіджі А. М., Гнедько Т. М. Функціонування конверсивів у текстах різних стилів

Анотація. Явище конверсії цікавить учених уже протягом багатьох століть, оскільки є одним з основних способів словотворення в англійській мові, а в останні десятиріччя виявляється одним із найпродуктивніших. I, незважаючи на її поширеність і активність у сучасній англійській мові, наявність великої кількості досліджень та думок питання щодо конверсії, ії видів, функцій та особливостей, вживання лишається одним із найбільш актуальних.

Явище конверсії настільки активне в сучасній англійській мові, що до нього практично залучаються, хоча i 3 неоднаковою частотою, слова всіх частин мови: іменники, дієслова, прикметники. Більше того, конверсія найбільш характерна саме для англійської мови з таких причин: по-перше, внаслідок іiі аналітичного ладу і майже повної відсутності в ній морфологічних показників частин мови (вони або не розрізняються зовсім, або можуть розрізнятися по словотворчих афіксах); по-друге, це явище тісно пов'язане з історією англійської мови, адже в староанглійській мові для творення нових слів широко використовувався його основний словарний склад, односкладові слова, з яких створювалися нові слова шляхом афіксації і словоскладання.

Конверсія як засіб словотвору широко використовується в текстах різних стилів. У запропонованій статті досліджуються ступені поширення конверсивів у текстах різних стилів, спираючись саме на їхні жанрово стильові характеристики, та аналізуються функції слів, утворених даним способом словотвору, з метою подальшого встановлення найбільш еквівалентних та адекватних способів їх перекладу 3 англійської мови на українську (в якій цей спосіб словотвору $є$ майже відсутнім) у текстах різних стилів та жанрів. У кожному з випадків вона виконує свої певні функції: у художньому тексті - зображує індивідуальний стиль автора, особливий діалект чи спосіб мовлення персонажу або його світосприйняття; у науковому тексті - використовується як засіб компресії інформації, конкретизації, лаконізму; у публіцистичному тексті - виконує експресивну функцію, використовується для узагальнення, економії мовних засобів. Цей засіб словотвору є не однаково поширеним у текстах різних стилів.

Ключові слова: словотвір, конверсія, морфологічні показники, жанрово-стильові характеристики, експресивна функція, компресивна функція. 